14. Лукичева, Л.И. Внутрифирменное управление интеллектуальными активами [Текст] / Л.И Лукичева, Д.Н. Егорычева - М.: Омега-Л, 2004.

15. Макаров, В.Л. Микроэкономика знаний [Текст] / В.Л. Макаров, Г.Б. Клейнер - М.: Экономика, 2007.

16. Мильнер, Б.3. Управление знаниями. Эволюция и революция в организации. [Текст] / Б.3. Мильнер, - М.: ИНФРА-М, 2003.

17. Мильнер, Б.3., Управление знаниями в корпорациях. [Текст] / Б.3. Мильнер, 3.П. Румянцева, В.Г. Смирнова и др. - М.: Дело, 2006.

18. Шипуліна, Ю.С. Управління розвитком інноваційного потенціалу промислових підприємств [Текст] / Ю.С. Шипуліна // Проблеми управління інноваційним розвитком підприємств у транзитивній економіці: монограф.; за заг. ред. д.е.н., проф. С.М. Ілляшенка. - Суми: ВТД "Університетська книга", 2005. - С. 174 - 231.

Отримано 3.09.2017

УДК 339.138

\title{
Світлана ШПИЛИК
}

\author{
Тернопільський національний технічний університет \\ імені Івана Пулюя, Тернопіль, Україна
}

\section{УПРАВЛІНСЬКИЙ ІНСТРУМЕНТАРІЙ ОЦІНЮВАННЯ ЕФЕКТИВНОСТІ ВПРОВАДЖЕННЯ КОНКУРЕНТНОЇ СТРАТЕГІЇ ЯК МЕХАНІЗМУ ПІДВИЩЕННЯ КОНКУРЕНТОСПРОМОЖНОСТІ ПІДПРИЕМСТВА}

\begin{abstract}
Резюме. Оиінювання є завершальним етапом розроблення стратегій. Вона трунтується на доволі вичерпній інформації й полягає у визначенні можливих наслідків реалізації обраної стратегї. Стратегію неможливо оцінити лише за одним узагальнюючим показником, тому щзо вона охоплює різні напрями діяльності організації. Оиінюють стратегію за якістю запланованих дій та успішністю їх реалізаџії. Іноді розроблення стратегії заслуговує високої оцінки, однак ї̈ впровадження не дає очікуваних результатів, наприклад, невдало організоване управління порушило заплановані терміни переходу на випуск нової продукції, внаслідок чого організачія зазнала збитків. Головним критерієм якості обраної стратегї вважають економічні результати розвитку організації.

Ключові слова: стратегія, маркетингова стратегія, конкурентна стратегія, стратегічний господарський підрозділ, SWОT-аналіз, маркетинг-мікс.
\end{abstract}

\section{Svitlana SHPYLYK}

Ternopil Ivan Pul'uj National Technical University, Ternopil, Ukraine

$$
\begin{gathered}
\text { MANAGEMENT INSTRUMENTS FOR EVALUATION OF } \\
\text { IMPLEMENTATION EFFICIENCY OF COMPETITIVE STRATEGY } \\
\text { AS A MECHANISM OF ENTERPRISE COMPETITIVENESS } \\
\text { ENHANCEMENT }
\end{gathered}
$$

Summary. The evaluation is the final stage in the development of strategies. It is based on rather comprehensive information and is to determine the possible consequences of implementing the chosen strategy. The strategy can not be estimated by only one general indicator, because it covers the various activities of the 
organization. The strategy is evaluated by the quality of the planned actions and the success of their implementation. Sometimes the development of a strategy deserves a high score, but its implementation does not provide the expected results, for example, the failure of organized management violated the planned timing of the transition to the release of new products, resulting in the organization suffered losses. The main criterion for the quality of the chosen strategy is the economic results of the organization's development.

Key words: strategy, marketing strategy, competitive strategy, strategic business units, SWOT-analysis.

Постановка проблеми. Для будь-якого економічного суб’єкта можливість прогнозування ситуації означає, насамперед, отримання кращих результатів або уникнення втрат. Усі взаємозв'язки змінних можуть бути оцінені кількісно, що дає змогу отримати високоякісний надійний прогноз. Важливим показником успішності діяльності будь-якого підприємства є обсяг реалізації його продукції, динаміка якого показує розширення (звуження) діяльності, стабільність розвитку.

Стратегічний маркетинг у системі управління конкурентною стратегією дає змогу виконати такі основні завдання: систематизувати дані маркетингових досліджень, формувати й удосконалювати бази даних у сфері дослідження конкурентного ринку; систематично й постійно аналізувати ключові потреби споживачів; уточнювати місію підприємства, що визначається їхньою економічною діяльністю та позицією на ринку, й формувати стратегічні конкурентні цілі; розробляти концепції успішних товарів, що дають підприємствам змогу обслуговувати обрані групи споживачів краще, ніж конкуренти, i гарантуватимуть їм стійкі конкурентні переваги; забезпечувати збалансованість структури товарного портфеля підприємств; розробляти конкурентні маркетингові стратегії розвитку підприємств; приймати рішення за елементами маркетингового комплексу; інтегрувати діяльність усіх структурних підрозділів і служб підприємств у сфері ефективного управління конкурентною стратегією, що забезпечить, оптимізацію внутрішньофірмового управління підприємствами.

Аналіз останніх досліджень і публікацій. Питанням оцінювання ефективності маркетингової конкурентної стратегії в умовах конкурентної боротьби на локальних ринках приділена значна увага переважно у працях російських економістів Г.Л. Азоєва, А.П. Градова, Р.А. Фатхутдінова, А.Ю Юданова. Їхні дослідження багатопланові, поєднують кількісний та якісний підходи. Вивченням методології управління конкурентними перевагами різних об'єктів господарської діяльності присвячено роботи як закордонних учених-економістів - I. Ансоффа, Ф. Котлера, М. Портера, А. Томпсона, так і вітчизняних дослідників - Е. М. Азаряна, Л. В. Балабанової, В.В. Холод, Н. В. Куденко та ін. $[1 ; 2 ; 6 ; 9 ; 11 ; 13]$.

Проте багато питань залишаються не вирішеними або дискусійними. Йдеться, передусім, про обгрунтування методів і прийомів дослідження, на основі яких здійснюють оцінювання конкурентної стратегії розвитку підприємства, визначення теоретичного й прикладного значення стратегічного аналізу в підвищенні ефективності менеджменту підприємств. Отже, є нагальна необхідність забезпечити системність дослідження механізму оцінювання стратегії підприємства. Необхідність дослідження цієї проблеми на належному рівні та з урахуванням специфіки й особливостей розвитку ринкових відносин в Україні зумовила вибір теми та визначила мету дослідження.

Мета статті - розроблення теоретико-методичних положень та пропозицій щодо формування механізму оцінювання конкурентної стратегії діяльності підприємств на основі вдосконалення маркетингового інструментарію.

Виклад основного матеріалу. Для дослідження та оцінювання стратегій можна застосувати оригінальну методику, яка передбачає: формування переліку показників визначення економічного зростання; встановлення нормативних співвідношень між темпами зростання цих показників, тобто побудову нормативної структури показників відповідно до конкретних умов; вибір нормативної структури показників з урахуванням 
особливостей ситуації; визначення фактичної структури показників, яка відображає реальний стан організації; оцінювання відповідності між нормативною та фактичною структурою показників; виявлення зовнішніх і внутрішніх чинників, які визначають фактичну структуру показників і ступінь їхнього впливу; формулювання висновків про результативність діючих у минулому стратегій і доцільність розроблення нової стратегії.

Сформувати перелік показників, які описують структуру економічного зростання та відображають рівень досягнення цілей розвитку, в міру ускладнення умов виробництва й збуту продукції, підвищення вимог до якості й безпеки товару стає все складніше. Окрім цього, показники, які використовують для оцінювання, можуть змінювати свою важливість відповідно до умов зовнішнього середовища, ЖЦТ і стратегічних цілей організації. Перелік показників, які підлягають оцінюванню, має забезпечити опис різних станів організації та враховувати такі чинники, як цілі організації, специфіку галузі, тип стратегії, особливості ринкової ситуації тощо. Розрізняють два способи формування складу показників оцінювання: експертний (експертами переважно $є$ керівники вищого рівня, які визначають стратегічні цілі організації та несуть основну відповідальність за їх досягнення) і логічний (дослідник враховує умови інтенсивного типу розвитку).

В основі методу дослідження й оцінювання стратегії лежить такий тип економічного зростання, при якому передбачені вищі темпи зниження витрат живої праці порівняно з витратами уречевленої праці та збільшення частки прибутку в створеній вартості, тобто забезпечення розширеного виробництва. На основі цього формується нормативна структура (нормативний ряд) темпів зростання показників розвитку організації $T$

$$
T_{3 n}<T_{c n}<T_{\mathcal{~} \mathrm{B}}<T m n<T n \text {, }
$$

де зn - трудові витрати (заробітна плата); $c n$ - повна собівартість товарної продукції; мв - матеріальні витрати; $m n$ - вартість товарної продукції; $n$ - прибуток [3, с. 252].

Цей нормативний ряд показників не може бути спадним. Отже, значення показника темпу зростання трудових витрат $\epsilon$ найнижчим, а темпи зростання прибутку - найвищими. Тобто результативні показники мають зростати швидше порівняно з показниками, які відображають темпи зростання ресурсів.

Нормативний ряд показників визначає умови розроблення та впровадження стратегії, за яких організація може підвищувати свої потенційні можливості, реалізувати переваги. Фактичний ряд показників може мати іншу їх послідовність. Порядок розміщення показників відображає певний стан організації, зумовлений характеристиками обраної стратегії. Варто зазначити, що поданий набір показників можна доповнювати, але надто велика їхня кількість знижує обгрунтованість стратегії.

Ступінь відповідності нормативного та фактичного рядів показників визначають за коефіцієнтом рангової кореляції (коефіцієнт Спірмена), який $\epsilon$ агрегованою характеристикою економічних результатів діяльності організації, що дає змогу відстежувати загальну тенденцію їх зміни внаслідок реалізації стратегії. Однак при цьому не враховуються чинники, які зумовлюють певні пропорції показників. До таких чинників належать технологія виробництва, продукція, основні виробничі фонди тощо. Отже, подальше дослідження реалізації стратегії можливе під час її реалізації й передбачає визначення того, як за цими чинниками оцінити рівень і пропорції діяльності організації.

Оцінювання стратегії передбачатиме прогноз можливих тенденцій кожного 3 перелічених показників і порівняння їх 3 нормативним рядом показників, що дає 
можливість оцінити вибір стратегії розвитку організації. Основним критерієм цього вибору є досягнення цілей організації.

Важливо визначити також рівень ризику, в умовах якого стратегія реалізується. Для цього можна скористатися формулою Z-чинника Альтмана [3, C. 255].

$$
Z=3,3 x_{1}+1,0 x_{2}+0,6 x_{3}+1,4 x_{4}+1,2 x_{5},
$$

де $x_{1}$ - відношення прибутку (перед сплатою податків і процентів) до суми активів; $x_{2}-$ відношення обсягу продажу продукції до активів; $x_{3}$ - відношення власного капіталу до залученого; $x_{4}$ - відношення чистого прибутку до активів; $x_{5}-$ відношення власних оборотних коштів до активів організації.

Критичне значення чинника, розраховане відомим західним економістом Е. Альтманом за даними статистичної вибірки, становить 2,675. 3 цією величиною порівнюють розрахункове значення показника для конкретної організації, що дає змогу прогнозувати в недалекому майбутньому (два - три роки) банкрутство $(Z<2,675)$ чи стійке фінансове положення $(Z>2,675)$ організацій.

Оцінювання вибраної стратегії $\epsilon$ необхідним елементом стратегічного планування, хоча задовільні методики її проведення тільки розробляються.

Досягнення високого рівня конкурентоспроможності підприємства, розроблення ефективної його стратегії неможливі без передбачення майбутнього, без прогнозування перспектив розвитку. Багато українських підприємств не поспішають використовувати прогнозування, що і є однією з причин виникнення суперечностей між внутрішнім середовищем підприємства та його стратегією.

Основні суперечності між внутрішнім середовищем підприємства та його стратегією наведено у табл. 1.

Таблиця 1

Деякі можливі суперечності між внутрішнім середовищем та конкурентною стратегією

\begin{tabular}{|c|c|c|}
\hline $\begin{array}{l}\text { Конку- } \\
\text { рентна } \\
\text { стратегія }\end{array}$ & Найменування суперечностей & $\begin{array}{c}\text { Наслідки виникнення } \\
\text { суперечностей }\end{array}$ \\
\hline 1 & 2 & 3 \\
\hline \multirow{5}{*}{ 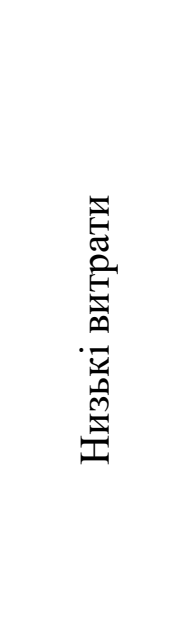 } & $\begin{array}{l}\text { 1. Зростання собівартості продукції швидше; } \\
\text { зростання обсягів виробництва }\end{array}$ & $\begin{array}{l}\text { 1. Унеможливлює досягнення } \\
\text { конкурентних переваг за } \\
\text { рахунок низьких витрат }\end{array}$ \\
\hline & $\begin{array}{l}\text { 2. Високі маркетингові витрати; висока } \\
\text { матеріаломісткість продукції; відсутність } \\
\text { ресурсозберігаючих технологій; великі витрати } \\
\text { на наукові розробки; придбання дорогих } \\
\text { сторонніх інновацій }\end{array}$ & $\begin{array}{l}\text { 2. Збільшення собівартості } \\
\text { продукції }\end{array}$ \\
\hline & 4. Постійні зміни в номенклатурі продукції & $\begin{array}{l}\text { 4. Збільшення витрат на розробку } \\
\text { нових видів продукції }\end{array}$ \\
\hline & $\begin{array}{l}\text { 9. Низький рівень автоматизації виробництва; } \\
\text { наявність втрат робочого часу }\end{array}$ & 9. Збільшення трудових витрат \\
\hline & 16. Низька виробнича дисципліна & 16. Втрати робочого часу \\
\hline
\end{tabular}


Закінчення таблиці 1

\begin{tabular}{|c|c|c|}
\hline 1 & 2 & 3 \\
\hline \multirow{6}{*}{ 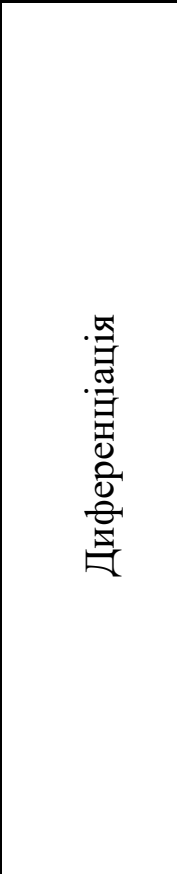 } & $\begin{array}{l}\text { 1. Застаріле обладнання; низька ритмічність } \\
\text { роботи; низький рівень автоматизації } \\
\text { виробництва; застарілі технології; низька } \\
\text { кваліфікація та досвідченість персоналу; низька } \\
\text { мотивація персоналу }\end{array}$ & $\begin{array}{l}\text { 1. Втрати часу, нижчий рівень } \\
\text { якості продукції, можливий } \\
\text { брак у виробництві }\end{array}$ \\
\hline & $\begin{array}{l}\text { 2. Низькі темпи зміни номенклатури продукції; } \\
\text { відсутність унікальності; низькі витрати на } \\
\text { здійснення науково-технічних розробок та } \\
\text { досліджень; тривалий час реалізації } \\
\text { управлінських рішень; тривалий час } \\
\text { виходу на ринок з новою продукцією }\end{array}$ & $\begin{array}{l}\text { 2. Втрата конкурентної переваги } \\
\text { у новизні продукції чи } \\
\text { унікальності }\end{array}$ \\
\hline & 10. Низькі маркетингові витрати & $\begin{array}{l}\text { 10. Можливі зменшення ринків } \\
\text { 3буту, кількості покупців }\end{array}$ \\
\hline & 11. Відсутність торгової марки & 11. Можливі втрати потенційних \\
\hline & 12. Низька якість продукції & 12. Втрата потенційних покупців \\
\hline & 14. Відсугність патентного захисту технологій & $\begin{array}{l}\text { 14. Недовге використання } \\
\text { технологічної переваги }\end{array}$ \\
\hline $\begin{array}{l}\text { Фокусу- } \\
\text { вання на } \\
\text { низьких } \\
\text { витратах }\end{array}$ & \multicolumn{2}{|c|}{$\begin{array}{l}\text { Суперечності характерні для стратегії низьких витрат з урахуванням } \\
\text { сегмента ринку }\end{array}$} \\
\hline $\begin{array}{l}\text { Фокусу- } \\
\text { вання на } \\
\text { дифе- } \\
\text { ренціації }\end{array}$ & \multicolumn{2}{|c|}{$\begin{array}{l}\text { Суперечності характерні для стратегії диференціації з урахуванням } \\
\text { сегмента ринку }\end{array}$} \\
\hline
\end{tabular}

Джерело: складено автором на основі [13; с. 280].

Одним із засобів, що допомагає своєчасно виявити можливі суперечності, є прогнозування. Прогноз - це науково обгрунтоване судження щодо стану об'єкта в певний момент часу. Для того, щоб прогноз був основою розробки стратегії управління підприємством, він має бути спрямований на вирішення технічних та організаційноекономічних проблем; проблем, пов'язаних із матеріально-технічним забезпеченням процесу виробництва та обсягом виробництва продукції у конкурентів та потребою в ній на ринку, собівартістю розроблення і виробництва цієї продукції та ії ціною; потужністю підприємства, необхідною для розроблення й виготовлення нової продукції; потребою у трудових ресурсах.

Прогноз має включати в себе аналіз розвитку прогнозованого напрямку виробництва й характеристику його стану; виявлення перспектив технічних i господарських проблем; оцінювання важливості досліджень. Прогнозування буде ефективним тільки у випадку, якщо вірогідність настання подій, що спричинені якимось плановим рішенням, яке прийняте тепер, достатньо велика.

Інструментарієм для розроблення й побудови моделі підвищення конкурентоспроможності та реалізації конкурентної стратегії може служити застосування математичного моделювання, що дозволяє виявити особливості функціонування економічного об'єкта, й на основі цього передбачати майбутню поведінку об'єкта при зміні яких-небудь параметрів. Для будь-якого економічного 
суб'єкта можливість прогнозування ситуації означає, перш за все, отримання кращих результатів або уникнення втрат. У моделі всі взаємозв'язки змінних можуть бути оцінені кількісно, що дозволяє отримати якісніший і надійніший прогноз. Важливим показником успішності діяльності будь-якого підприємства є обсяг реалізації його продукції, динаміка якого показує розширення (звуження) діяльності, стабільність розвитку.

Існує три основних методи, які дозволяють приймати рішення з урахуванням фактора невизначеності та які підтримує Excel: стандартні відхилення, довірчі інтервали та множинний регресійний аналіз.

Стандартне (середнє квадратичне) відхилення - це ступінь відхилення усіх значень ознаки від свого середнього показника. Стандартне відхилення $є$ одним із найважливіших методів, що допомагають визначити, наскільки змінюється певна величина: чим більше стандартне відхилення, тим ширший діапазон змін значень цієї величини.

На значення довірчих інтервалів впливають кілька факторів, одним 3 яких є стандартне відхилення результатів спостережень. 3 цим фактором нічого не можна зробити, оскільки він базується на даних, отриманих у результаті цих спостережень.

Іншим фактором є точність (рівень надійності), значення його можна регулювати. Чим більша ширина довірчого інтервалу, тим вища точність оцінювання. Отже, дослідник стикається 3 вибором: можна зменшити інтервал, зменшивши рівень надійності, наприклад, до90 \%, але при цьому не тільки зменшиться інтервал, а й знизиться ступінь довіри до отриманих оцінок. А можна збільшити розміри вибірки спосіб зменшення інтервалу із збереженням при цьому прийнятного ступеня довіри. Проте повної гарантії точності оцінювання останній спосіб не дає. Може навіть статися, що зростання розмірів вибірки призведе до зростання стандартного відхилення. I це обов'язково станеться, якщо отримані додаткові результати спостережень досить значно відрізнятимуться від середнього значення попередньої вибірки.

Регресійний і кореляційний аналізи - це дуже ефективні методи, які дозволяють аналізувати значні обсяги інформації з метою дослідження ймовірного взаємозв'язку двох чи більше змінних. У регресійному аналізі розглядається зв'язок між однією змінною, що називається залежною змінною, або ознакою, й кількома іншими, що називаються незалежними змінними. Цей зв'язок представляється за допомогою математичної моделі, тобто рівняння, яке зв'язує залежну змінну $(y)$ з незалежними $(x) 3$ урахуванням множини відповідних припущень. Оскільки метою регресійного аналізу є виявлення впливу змінних $x$ на значення змінної $y$, останню ще називають відгуком, або результативним фактором, а змінні $x$ - факторами, що впливають на відгук. Регресійний аналіз використовується 3 двох причин. По-перше, тому що опис залежності між змінними допомагає встановити наявність можливого причинного зв'язку. По-друге, отримання аналітичної залежності між змінними дає змогу передбачати майбутні значення залежної змінної за значеннями незалежних змінних.

Для виявлення можливих суперечностей між внутрішнім середовищем та конкурентною стратегією пропонується методичний підхід, який передбачає побудову багатофакторної динамічної моделі. Етапи прогнозування суперечностей між внутрішнім середовищем та стратегією підприємства:

1. До початку здійснення процесу прогнозування визначаються стратегічні цілі, яких планує досягти підприємство в певному періоді.

2. Аналіз об'єктів прогнозування починається на стадії передпрогнозних досліджень, коли визначаються цілі та задачі прогнозування. В постановці задачі мають міститися мета і призначення прогнозу, терміни його проведення, відповідальні за проведення. Постановка проблеми повинна спиратися на фундаментальні теоретичні положення економіки, глибоке знання змістовної основи питання й формулюватися у 
відповідності з законами, категоріями, природою економічних показників. Аналіз об'єкта прогнозування проводиться на всіх етапах побудови й реалізації прогнозу, забезпечуючи при цьому необхідну інформацію для уточнення, коригування прогнозу.

3. Обирається метод прогнозування. Для здійснення прогнозу в практиці прогнозування використовуються різні методи.

Вибір методу прогнозування залежить від мети, особливостей об'єкта прогнозування, наявної інформації про нього та його оточення. На цьому етапі важливо врахувати період упередження прогнозу та зіставити його 3 ймовірною тривалістю еволюційного етапу розвитку об'єкта.

При виборі методу прогнозування слід вирішити такі проблеми: який саме тип прогнозу необхідно побудувати (короткотерміновий, середньотеріновий, довготерміновий; мікро-, мезо- чи макропрогноз); яка форма вихідних статистичних даних, на основі яких будується прогноз; для кого призначений прогноз (керівництво підприємства, служба маркетингу); які необхідні точність прогнозу та витрати для забезпечення прогнозу.

Важливими факторами, які впливають на вибір методу прогнозування, є витрати й точність. Найкращий прогноз не обов'язково має бути найточнішим чи найдешевішим - скоріше, він являє собою деяку комбінацію точності та вартості, яку керівництво вважає оптимальною.

Іншими факторами, які необхідно враховувати при виборі методу прогнозування, $€$ : наявність статистичних даних за певний період часу; компетенція прогнозувача; час, необхідний для підготовки прогнозу; попередній досвід використання певного методу.

Із сукупності існуючих статистичних методів прогнозування пропонується використовувати методи моделювання.

Методи моделювання базуються в основному на стохастичних моделях, які реалізуються на основі статистичної інформації. Однією із форм економікостатистичного моделювання є кореляційне моделювання, суть якого полягає в тому, щоб знайти математичний вираз, який буде відображати зв'язок досліджуваного показника i факторів, які його визначають, тобто реалізувати залежність такого вигляду:

$$
y=f\left(x_{1}, x_{2}, x_{3}, \ldots, x_{n}\right)
$$

4. Найважливішим етапом прогнозування $є$ вибір аналізованого показника та системи факторів, що на нього впливають. Як прогнозний слід використовувати показник, який значною мірою відображає прогнозоване явище. Як факторні ознаки слід вибирати показники, що визначають суть, зміст, рівень прогнозованих явищ.

До включених у модель факторів пред'являються певні умови [4]: фактори мають знаходитися в причинно-наслідкових зв'язках 3 досліджуваним показником; фактори мають бути кількісно вимірюваними, оскільки процедура реалізації моделей передбачає дії тільки з кількісними ознаками; фактори не повинні знаходитися між собою у тісному взаємозв'язку, тобто має бути відсутнім мультиколінеарний зв'язок; у модель не можуть бути включені фактори, якщо один 3 них є частиною іншого; в модель не можна включати фактори, які в певному сполученні функціонально взаємопов'язані 3 досліджуваними показниками; кожен фактор може бути включений до моделі тільки однією ознакою (натуральною або вартісною, абсолютною або відносною); в моделі треба використовувати мінімальну, але достатню кількість факторів.

Щоб виключити суб'єктивну оцінку ролі окремих факторів, здійснюється їх відбір. На першій стадії до моделі включаються всі передбачені фактори; на другій шляхом кількісного та якісного аналізу відсіюються незначні фактори. 
5. Вибір форми зв'язку (виду моделі) полягає в знаходженні аналітичного виразу, який відображає взаємозв'язок досліджуваного показника і факторів, що на нього впливають. Розроблена модель має відповідати таким умовам: будуватися на базі економічної теорії; відображати структуру досліджуваного процесу; система рівнянь, що формує модель, повинна задовольняти математичним вимогам.

При встановленні форми зв'язку найбільш точно і достовірно іiі характер відображає не підібрані за певними кількісними критеріями моделі, а випробувані на реальній економічній практиці. При виборі виду моделі необхідно оцінити, наскільки логічно та коректно (зі статистичної точки зору) відібрана модель та наскільки вона адекватна реальним процесам.

6. Параметри рівняння розраховуються методом найменших квадратів, який передбачає мінімізацію суми квадратів відхилень між фактичними й розрахунковими значеннями функції. На цьому етапі розраховуються коефіцієнт множинної кореляції (відображає щільність зв'язку в моделі), коефіцієнт детермінації (відображає частку впливу відібраних факторів на величину результативного показника).

7. Реалізована економіко-статистична модель має бути перевірена на статистичну надійність, що є умовою можливості використання цієї моделі в прогнозуванні. Для оцінювання адекватності та надійності моделі розраховуються: середня помилка апроксимації, критерій Стьюдента, критерій Фішера, коефіцієнти еластичності, бетакоефіцієнти.

8. На останньому етапі оцінюються результати прогнозування та робиться висновок про можливість досягнення поставлених стратегічних цілей. Якщо за результатами прогнозу цілі досягти можливо, то суперечностей між внутрішнім середовищем та стратегією не існує. Підприємство продовжує свій розвиток згідно 3 обраною стратегією. Якщо ж цілі згідно з прогнозом досягти неможливо, то це свідчить про наявність суперечностей, що потребує розроблення та здійснення заходів зі змін у внутрішньому середовищі або коригування стратегічних цілей.

У маркетинговій діяльності часто виникають ситуації, за яких доводиться приймати рішення, виходячи 3 недостатньо чітко визначених умов та оперуючи не завжди надійною інформацією. У таких випадках виникає потреба в оцінюванні ймовірності досягнення тих чи інших результатів

Використовуючи засоби Microsoft Excel, можна представити отримані дані у вигляді діаграми.

Згідно з загальною теорією статистичного кореляційно-регресійного аналізу [5, c. 76], коефіцієнт регресійного аналізу $b$ показує, як змінюються обсяги продажу підприємств при збільшенні значення витрат на рекламу й просування продукції на одиницю. Так як факторна ознака $x$ (витрати на просування) може набувати нульового значення, то коефіцієнт $a$ має не тільки розрахункове значення, а інтерпретується як значення обсягу виробництва при нульових витратах на просування. Коефіцієнт детермінації $R^{2}$ оцінює, наскільки варіація результативної ознаки $Y$ пояснюється варіацією фактора $X$ (інша частина варіації $Y$ пояснюється варіацією інших факторів).

Коефіцієнт кореляції $R$ оцінюе тісноту зв'язку між факторною й результативною ознаками й обчислюється за формулою [5, с. 82] 


$$
R=\sqrt{R^{2}}
$$

Значення показника змінюються в межах $0 \geq \mathrm{R} \geq 1$. Чим ближче значення $R$ до 1 , тим тісніше зв’язок між ознаками. Для якісного оцінювання тісноти зв'язку на основі $\mathrm{R}$ служить шкала Чеддока [14] (табл. 2).

Таблиця 2

Шкала Чеддока

Table 2

Chaddock Scale

\begin{tabular}{|c|c|c|c|c|c|}
\hline$R$ & $0,1-0,3$ & $0,3-0,5$ & $0,5-0,7$ & $0,7-0,9$ & $0,9-0,99$ \\
\hline $\begin{array}{c}\text { Характеристика } \\
\text { сили зв'язку }\end{array}$ & Слабка & Помірна & Помітна & Тісна & Дуже тісна \\
\hline
\end{tabular}

Доцільно вдосконалювати стратегічне планування діяльності. Процес реалізації розглянутої моделі аналізу є циклічним. Вона може застосовуватися для прогнозування фінансових результатів підприємства кожен місяць, квартал або рік залежно від потреб керівників підприємства в прогнозних даних для підтримання процесу прийняття управлінських рішень. 3 наведеного аналізу можна зробити висновок, що розглянута модель може змінюватися залежно від зміни зовнішніх умов, у яких працює підприємство (законодавство, конкуренція, вплив центральних та місцевих органів влади на регулювання економіки).

На нашу думку, для прогнозування різних параметрів функціонування будь-якого підприємства необхідно використовувати могутні засоби прогнозування. Вони повинні бути достатні для вирішення найскладніших завдань прогнозування. Застосування прогнозування при керуванні великими комерційними проектами повинне скоротити ризики необдуманих рішень і максимізувати прибуток. Застосування підсистеми прогнозування дозволить при прогнозуванні ряду відслідковувати співвідношення між отримуваним прогнозом одного ряду і розрахованим раніше прогнозом іншого ряду.

Для прогнозування ризикованих ситуацій необхідне використання засобів аналізу проектного ризику й анкетування, що повинні доповнити технологію до системи, яка забезпечує повну організаційно-технологічну підтримку управлінського процесу. Спільне використання цих підсистем дозволить охопити майже всі ключові стадії процесу аналізу.

Після вибору стратегії настає етап перетворення її в дію. Реалізація стратегії - це найменш формалізована частина стратегічного управління й найбільш невизначена 3 погляду кінцевого результату. Реалізація обраної стратегії підприємства пов'язана зі здійсненням стратегічних змін. Основним завданням стратегії $є$ досягнення ситуації, коли можна було вписатися в навколишнє економічне середовище й відповідати йому.

У процесі реалізації стратегії підприємство може зіштовхнутися з деякими проблемами, які необхідно вирішувати шляхом стратегічних змін. Враховуючи, що підприємство - це відкрита система, яка діє в динамічному оточенні, можна стверджувати, що дуже часто виникають обставини, які роблять коригування стратегії не тільки можливими, а й бажаними. Це відбувається в умовах, коли заплановані стратегічні заходи не спрацьовують, іноді - коли $є$ помилки щодо прогнозування 
розвитку ситуації. Навіть обгрунтована, добре впроваджувана стратегія іноді потребує часткового покращення.

Основним в управлінні розвитком підприємства виступає вміння бачити процес досягнення цілей діяльності підприємства в динаміці. Для ефективного розвитку підприємства найважливіше значення набуває швидкість змін. Основним питанням при цьому є досягнення рівноваги між змінами й стабільністю. Зміни на підприємстві проводяться для того, щоб у ньому створювалися умови, необхідні для реалізації обраної стратегії.

В умовах невизначеності та нестабільності зовнішнього середовища для підвищення успішності діяльності підприємства недостатньо спланувати та реалізувати модель дій. Розроблена система стратегічного планування передбачає постійну перевірку та коригування стратегії підприємства відповідно до змін, що відбуваються в межах зовнішнього та внутрішнього середовищ.

Успіх реалізації розробленої стратегії підприємства залежить від діючої системи стратегічного контролю, який здійснюється протягом періоду дії стратегії та передбачає аналіз і оцінювання виконання стратегічних рішень 3 точки зору відповідності стратегічного плану і ступеня досягнення стратегічних цілей. Оцінювання стратегії відбувається шляхом порівняння результатів діяльності 3 цілями. Процес оцінки використовується як механізм зворотного зв'язку для коригування стратегії. 3 метою підвищення ефективності оцінювання потрібно проводити системно та безперервно.

Проведення етапів стратегічного контролю входить до обов'язків керівників середньої ланки, а узгодження результатів та дій з коригування - до обов'язків директора підприємства.

Проблема оцінювання стратегічної позиції підприємства сконцентрована на питаннях ефективності стратегії, сильних та слабких сторонах підприємства, його конкурентоспроможності за цінами та витратами, конкурентній позиції, стратегічних результатах при реалізації стратегії, дієвості стратегії з точки зору провідних сил у галузі, відповідності стратегії ключовим факторам успіху в галузі, захищеності стратегії від п'яти сил конкуренції, напрямкам, у яких стратегія не може адекватно захистити підприємство від зовнішніх погроз і внутрішніх слабкостей, наявності конкурентних переваг. Розгляд цих питань має показати, чи може підприємство продовжувати розвивати існуючу стратегію 3 мінімальними змінами, чи необхідно іiі істотно коригувати.

Оцінювання застосованих стратегій слід здійснювати на основі результатів їхньої реалізації, що визначається показниками діяльності підприємства. При цьому необхідно врахувати основні концептуальні посилання оцінювання стратегії: використання ситуаційного підходу до добору показників; розгляд підприємства як відкритої системи й визначення зовнішньої і внутрішньої успішності; використання узагальнюючих показників досягнення результатів; доповнення економічних показників ефективності

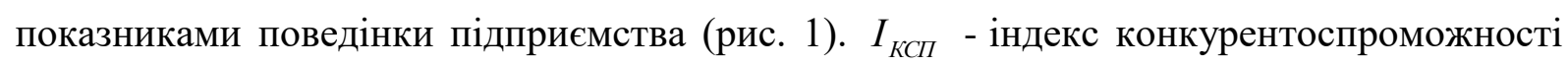
підприємства, який розраховується після проведення експертного оцінювання показників зовнішньої та внутрішньої успішності стратегії. 


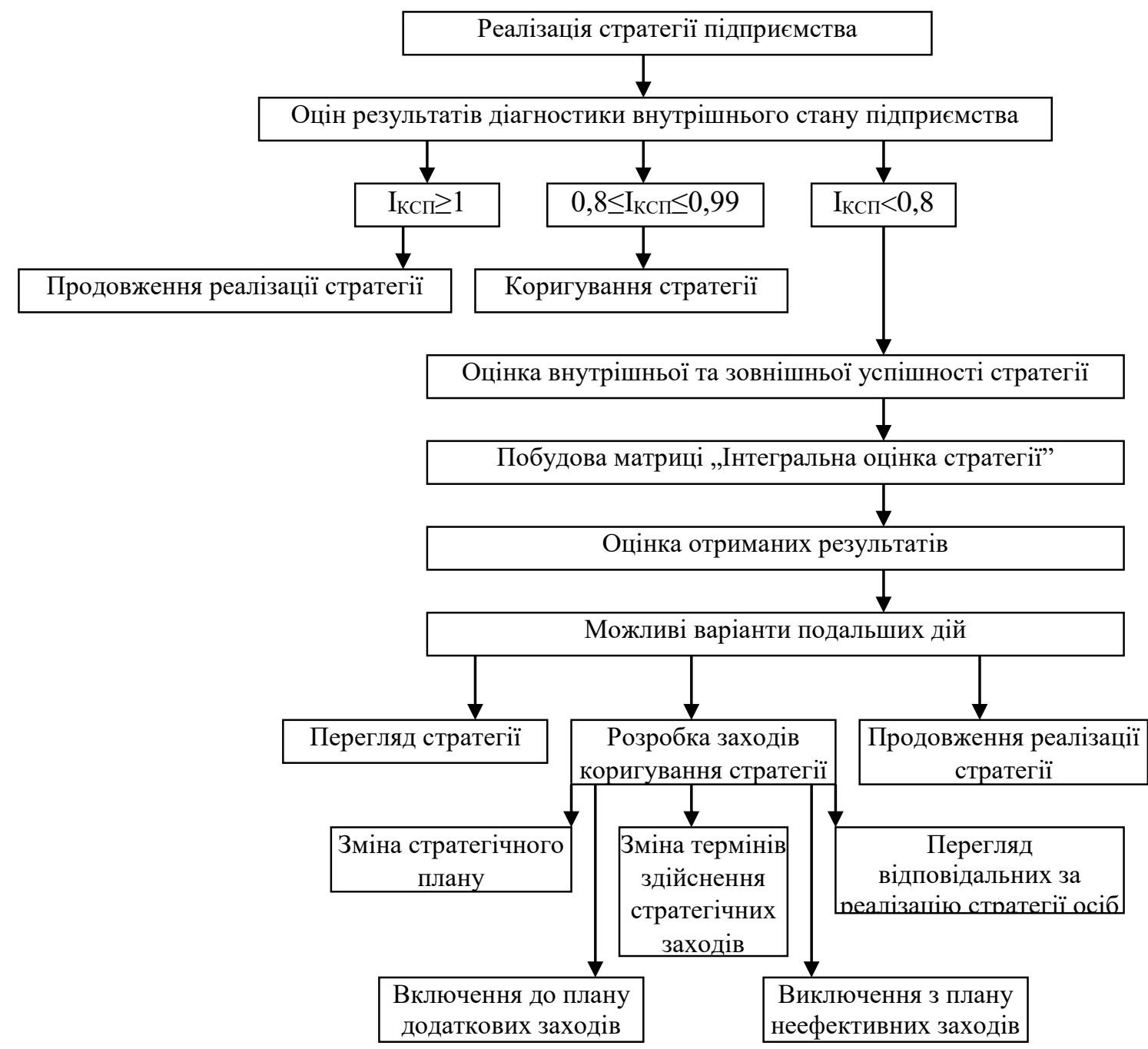

Рисунок 1. Загальна схема оцінки успішності реалізації стратегії

Джерело: побудовано автором на основі [10].

Обгрунтований підхід до коригування стратегії підприємства полягає в такому [10; c. 298]:

1. В процесі реалізації стратегії здійснюється діагностика стану внутрішнього середовища $з$ метою виявлення „вузьких” місць та конкурентних переваг підприємства та оцінювання результатів діагностики.

2. Далі здійснюється та приймається одне з трьох рішень: продовження реалізації стратегії, іiі коригування, оцінювання успішності стратегії підприємства.

3. Оцінювання успішності стратегії передбачає розрахунок показників внутрішньої та зовнішньої успішності стратегії, яку пропонуємо здійснювати шляхом порівняння планових та фактичних показників діяльності підприємства. На їх основі формують інтегральні показники успішності стратегії (IBУC, IЗУC), що розраховують за формулами

$$
I_{B У C}=\sqrt[n]{\prod_{1}^{n} \Pi_{B Y C}}
$$




$$
I_{3 У C}=\sqrt[n]{\prod_{1}^{n} \Pi_{3 Y C}}
$$

де ПВУС - показники внутрішньої успішності стратегії;

ПЗУС - показники зовнішньої успішності стратегії;

$\mathrm{n}$ - кількість показників, що використані для оцінювання.

Зовнішня успішність стратегії відображає ступінь відповідності діяльності підприємства вимогам зовнішнього оточення та адаптивності до змін, що відбуваються в зовнішньому середовищі.

Внутрішня успішність стратегії відображає відповідність результатів, яких досягло підприємство, поставленим цілям.

Для оцінювання внутрішньої та зовнішньої успішності стратегії автор пропонує використовувати такі показники:

Внутрішня успішність: 1) обсяг виробництва; 2) чистий прибуток; 3) загальна рентабельність; 4) оборотність обігових засобів; 5) собівартість продукції; 6) фондовіддача.

Зовнішня успішність: 1) обсяги реалізації; 2) темпи змін ринків збуту; 3) темпи зміни кількості виграних тендерів; 4) витрати на придбання ресурсів; 5) рентабельність продажу; 6) темпи змін капіталовкладень у підприємство.

4. На основі поєднання оцінювання внутрішньої та зовнішньої успішності стратегії та оцінювання досягнення цілей будується матриця „інтегральна оцінка стратегіï" (рис. 2).

Розраховані значення внутрішньої та зовнішньої успішності стратегії оцінюються за отриманими за допомогою експертних методів градаціями:

від 0 до 0,4 - низький рівень успішності; від 0,5 до 0,7 - середній рівень успішності; від 0,8 до 1 - високий рівень успішності.

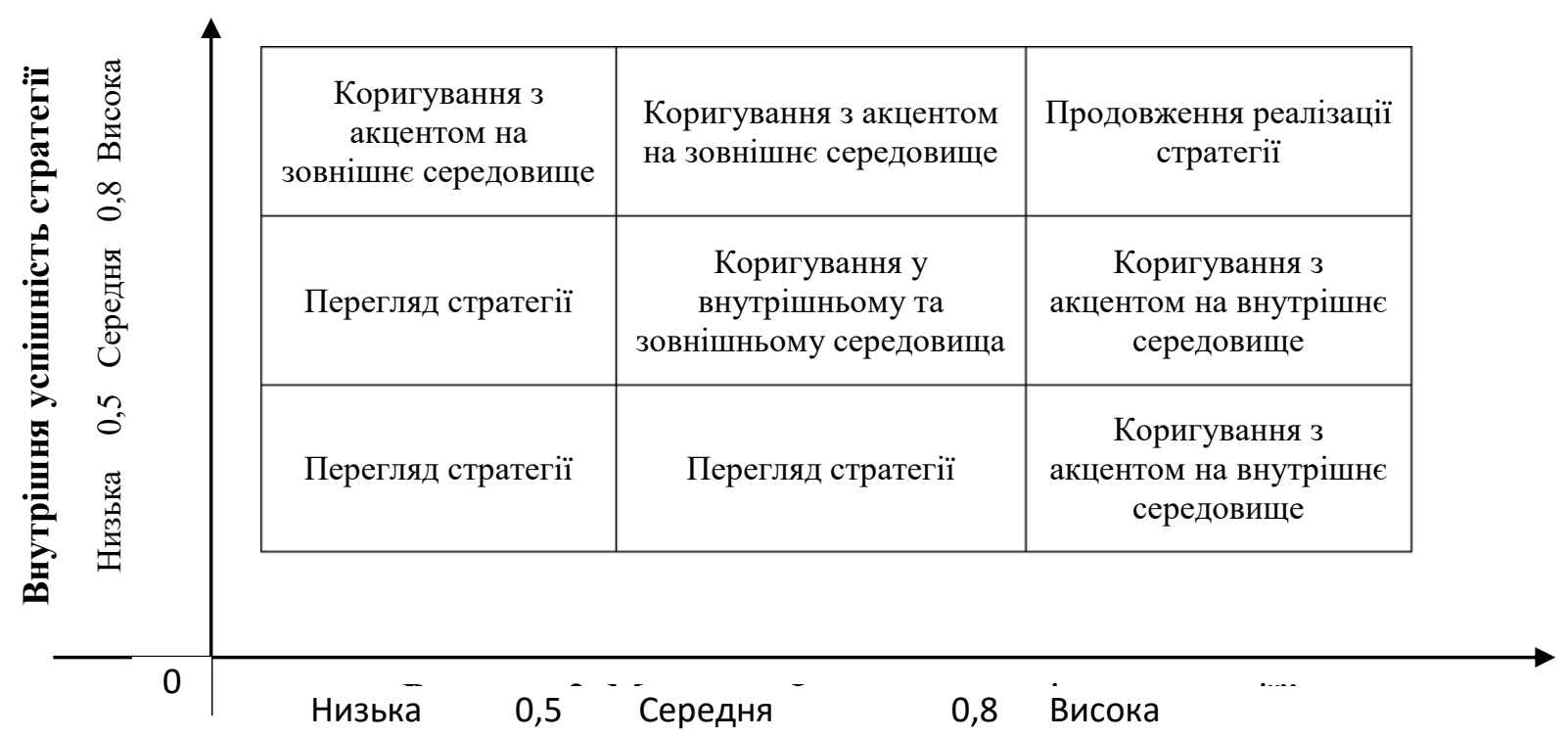

Рисунок 2. Матриця «інтегральна оцінка стратегії»

Джерело: побудовано автором на основі [10]. 
5. У результаті формується висновок про успішність стратегії, який відображає три варіанти подій: перегляд стратегії; коригування стратегії; продовження реалізації обраної стратегії.

6. На останньому етапі розробляється система заходів, які будуть спрямовані на зміну цілей чи на коригування стратегії досягнення цих цілей.

Стратегічні зміни - це основний конструктивний зміст стратегії. Саме стратегічні зміни є основними носіями нової якості в ході розвитку підприємства. Саме стратегічні зміни являють собою ключовий об'єкт управління в процесі реалізації стратегії.

Стратегічні зміни на підприємствах мають стосуватися стратегічного плану, що потребує зміни термінів здійснення стратегічних заходів, формування нових заходів реалізації стратегії, виключення недоцільних заходів. По-перше, це стосується зміни термінів здійснення маркетингових програм (з 1 до 1,5 року) та програм із освоєння нової техніки та технології (з 0,5 до 1 року), що має дозволити робітникам підприємства ефективніше здійснити ці програми. По-друге, до нових стратегічних заходів необхідно додати заходи, пов'язані зі здійсненням науково-технічних розробок, рекламних заходів, 3 покращенням рівня інформаційного потенціалу підприємства.

Висновки. У процесі реалізації стратегії підприємство може зіштовхнутися 3 проблемами, які необхідно вирішувати шляхом стратегічних змін. Система стратегічних змін має бути досить унікальною, гнучкою й адекватною стосовно зовнішнього середовища, охоплювати всі аспекти діяльності підприємства. Необхідність здійснення стратегічних змін встановлюється шляхом оцінювання стратегії підприємства, на основі результатів ii реалізації, що визначається показниками діяльності підприємства. В основу розробленого науково обгрунтованого підходу до коригування стратегії підприємства покладено визначення показників внутрішньої та зовнішньої успішності конкурентної стратегії та побудова матриці „інтегральна оцінка стратегії”.

У дослідженні запропоновано механізм оцінювання ефективності реалізованої стратегії. Інструментарієм для розроблення і побудови моделі служить застосування математичного моделювання, що дозволяє виявити особливості функціонування економічного об'єкту. Й на основі цього передбачати майбутню поведінку об'єкта при зміні яких-небудь параметрів. Для будь-якого економічного суб'єкта можливість прогнозування ситуації означає, перш за все, отримання кращих результатів або уникнення втрат. У моделі всі взаємозв'язки змінних можуть бути оцінені кількісно, що дозволяє отримати якісніший і надійніший прогноз.

\section{Використана література}

1. Азоев, Г.Л. Конкурентые преимущества фирмы [Текст] / Г.Л. Азоев, А.П. Челенков. - М.: ОАО „Типография „НОВОСТИ”, 2000. - 256 с.

2. Балабанова, Л.В. Стратегічне маркетингове управління конкурентоспроможністю підприємств: навч. посіб. [Текст] / Балабанова Л.В., Холод В.В. - К.: ВД „Професіонал”, 2006. - 448 с.

3. Кіндрацька, Г.І. Стратегічний менеджмент: навч. посіб. [Текст] / Г.І. Кіндрацька. - К.: Знання, 2006. $-366 \mathrm{c}$.

4. Книш, М.И. Конкурентные стратегии: учебное пособие [Текст] / М.И. Книш. - СПб.: Любавич, 2000. $-284 \mathrm{c}$.

5. Ковтун, Н.В. Загальна теорія статистики: курс лекцій [Текст] / Н.В. Ковтун, Г.С. Столяров. - К.: Четверта хвиля, 1996. - $144 \mathrm{c}$.

6. Куденко, Н.В. Маркетингові стратегії фірми: монографія [Текст] / Н.В. Куденко. - К: КНЕУ, 2002.$245 \mathrm{c}$. 
7. Шпилик, С.В. Методики оцінки ефективності впровадження стратегії [Текст] / С. В. Шпилик // Матеріали VII Міжнародної науково-теоретичної конференції „Соціально-економічні, політичні та культурні оцінки і прогнози на рубежі двох тисячоліть” (Тернопіль, 8 квітня 2009 р.). - Тернопіль, 2009. - C. $245-246$.

8. Пастухова, В. Стратегічне управління підприємством: філософія, політика, ефективність: монографія [Текст]. - К.: Нац. торг.-екон. ун-т, 2002. - 302 с.

9. Портер, М. Конкурентная стратегия. Методика анализа отраслей и конкурентов [Текст] / Майкл Портер [2-е изд.]. - М.: АльпинаБизнесБукс, 2006. - 454 с.

10. Теоретичні основи конкурентної стратегії підприємства: монографія [Текст]; за заг. ред. д-ра екон наук, професора Іванова Ю.Б., д-ра екон наук, професора Тищенка О.М. - Х.: ВД „ІНЖЕК”, 2006. $384 \mathrm{c}$.

11. Фатхутдинов, Р.А. Конкурентоспособность: экономика, стратегия, управление [Текст] / Р.А.Фатхутдинов. - М. : Инфра, 2000. - 312 с.

12. Шпилик, С.В. Конкурентна стратегія як засіб досягнення конкурентної переваги [Текст] / С.В. Шпилик // Галицький економічний вісник. - Тернопіль, 2008. - № 4. - С. 101 - 109.

13. Экономическая стратегия фирмы: учеб. пособие [Текст] / А.П. Градова. - 3-е изд., испр. - СПб.: Спец. лит, 2000. - 589 с.

14. http: // ru. wikipedia. org / wiki / Коэффициент детерминации.

Отримано 24.09.2017 